MINING IN THE TOLOVANA, HOT SPRTNG, AND RANPART DISTRICIS, 1960

During July 20 to 28,1960 , I traveled through the Tolovana, Hot Springe, and Rampart mining districts gto viaft mining operations. Two oneman minlng operations were ective in the Tolovana Dlatrloty four operatione employlng 16 men ware active in the farelca areai threo operations employing 6 men wore active in the Rampert District, and one old-tlmer from Rampart mined by hand pert time; there were no active mining operatione in the Tofty area.

The complation of the rand between Livengood and Bureka in the Fill of 1959 tied the old Tofty-Manley-inureke road network to the main roed gyotem of 1nterior Alaska, maldng the Maniey lot Springa District accessible by road from Falrbanks. The roed from Fal rbanke: to Ihrekar 18 a part of the proposed Falrbankgnome road, and surveys have been made westward fxom Ehreke preparatory to extending the road to the Yukon River. The now rood undowbtedy has rearlted in sone increase In economic activity at Manley Hot Springs, chiefly in sales of gasoline, grooer1es, and lodging. Most freight into the area still comes by river from Nenana or Falrbanks to Manley. In at least ono 1 ngtanco during 1960, a perty of prospectore spent several days in the aros under elrcumetances ouch that they probebly would not have done so 1 ff the area had not beon accessible by automobile. The road is a convenience to the mintine operators, and it eases the problem of obtalning repaix parts on short notice; by makd ng the area more eanily ecoesible to prospectors, it may oventually lead to now mining development.

To reach the Rampart District, I traveled on foot from Euroka Creok over the divide to Minook meek and down the valley of Minook Greek, followlng a winter dogeled trall that the Indians have used for 
many Jears. Becauge of a request by regldents of Rempart for the State to butld an access roed along this route, I took a nfmber of photographs of the terratn and aubmitted them in Auguat, 1960, In a folder entitled PHOTOGRAPRS TAKEN ALONG THE PURREARAMART TRAIL.

TOLOVANA DISTRICS.

Ben Follg mined dur1ng 1960 on Wilbur Greek. it the t1me of my

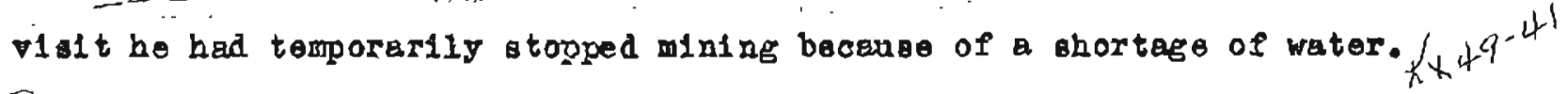
The depth of gravel. In his cut rarieg from 4 to 22 feet; the overlying inck 1850 fret thiaks The apper end of the out 1875 feet downotream from the boundary of a claim owned by Tony Radak of Livengood. The ground above Radak'o claim 1s ormed folntly by Ben Falls and Tony Indstrom. Ben doen not plan to start a new out abovo the Radak ground unless there is a mejor change in the economiog of gold mining. He

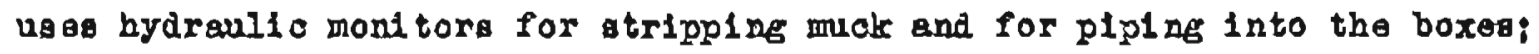
he 280 bulldozer for pushing to the head of the boxes and for staold ne talling:

The RedBtono Mining Go, owned and operated by Carl Henlager, 18 minlne near Itrengood Greek ono-half mile upitream from the camp bulldings that were bullt by Iivengood Placers. Inc. The present cut is $k \times 19+18$ on the left-limit sid of the valley but on the rightulimt side of the creok. Dab Caterplliar tractor 18 used for mining and staciling tall1ug; a slutceplate is aged at the head of the boxes. Water for elutelng comer from Ifrengood Creak, and there appears to be an abundanco of water. 


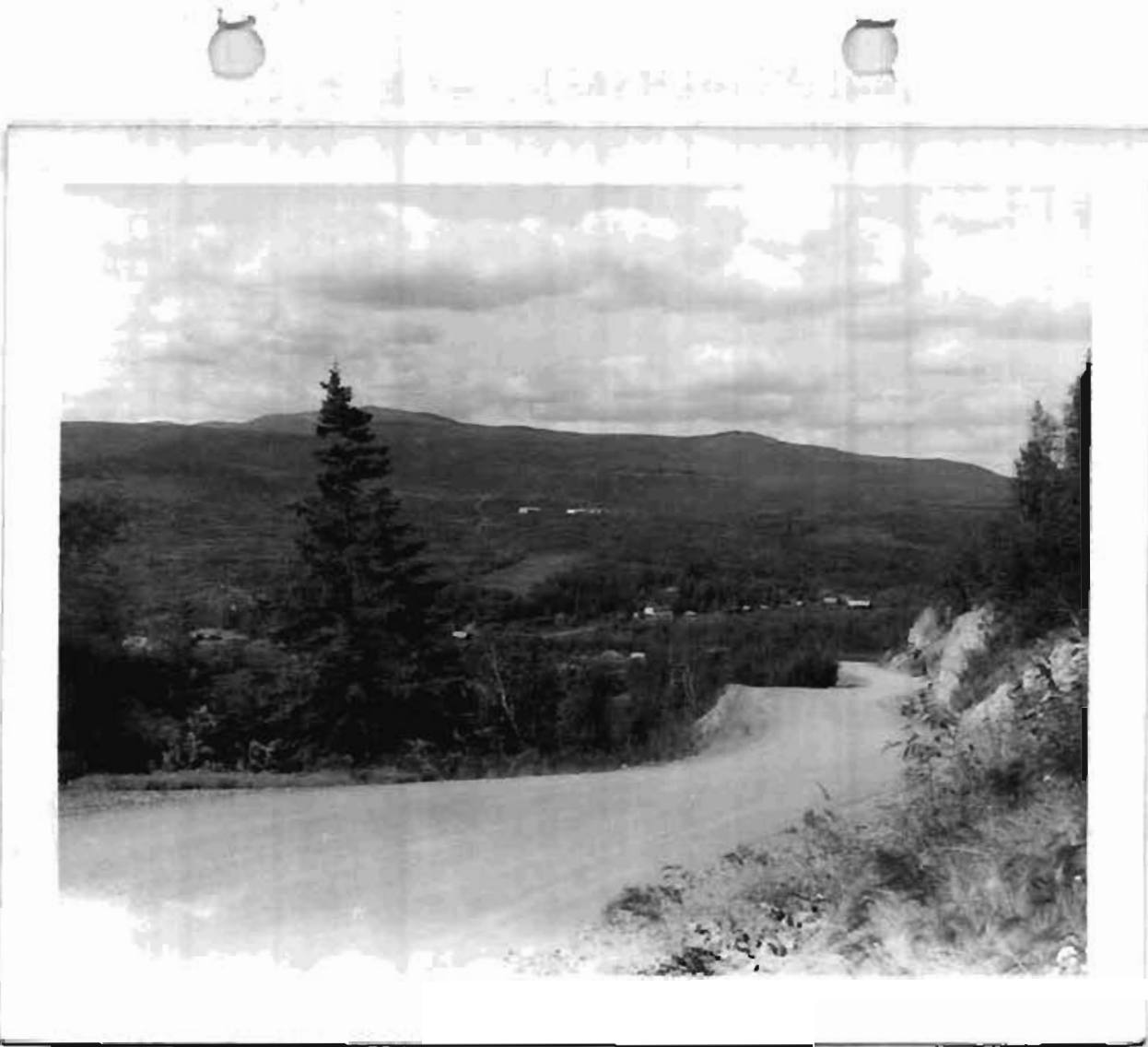

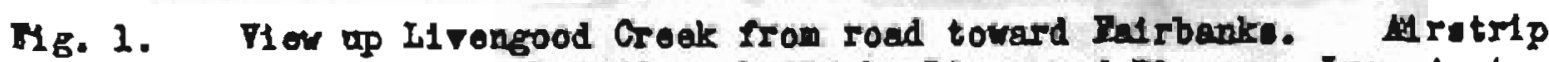
1. In canter, bulldingt ballt by Livengood Placers, Ino. just above alrotrip.

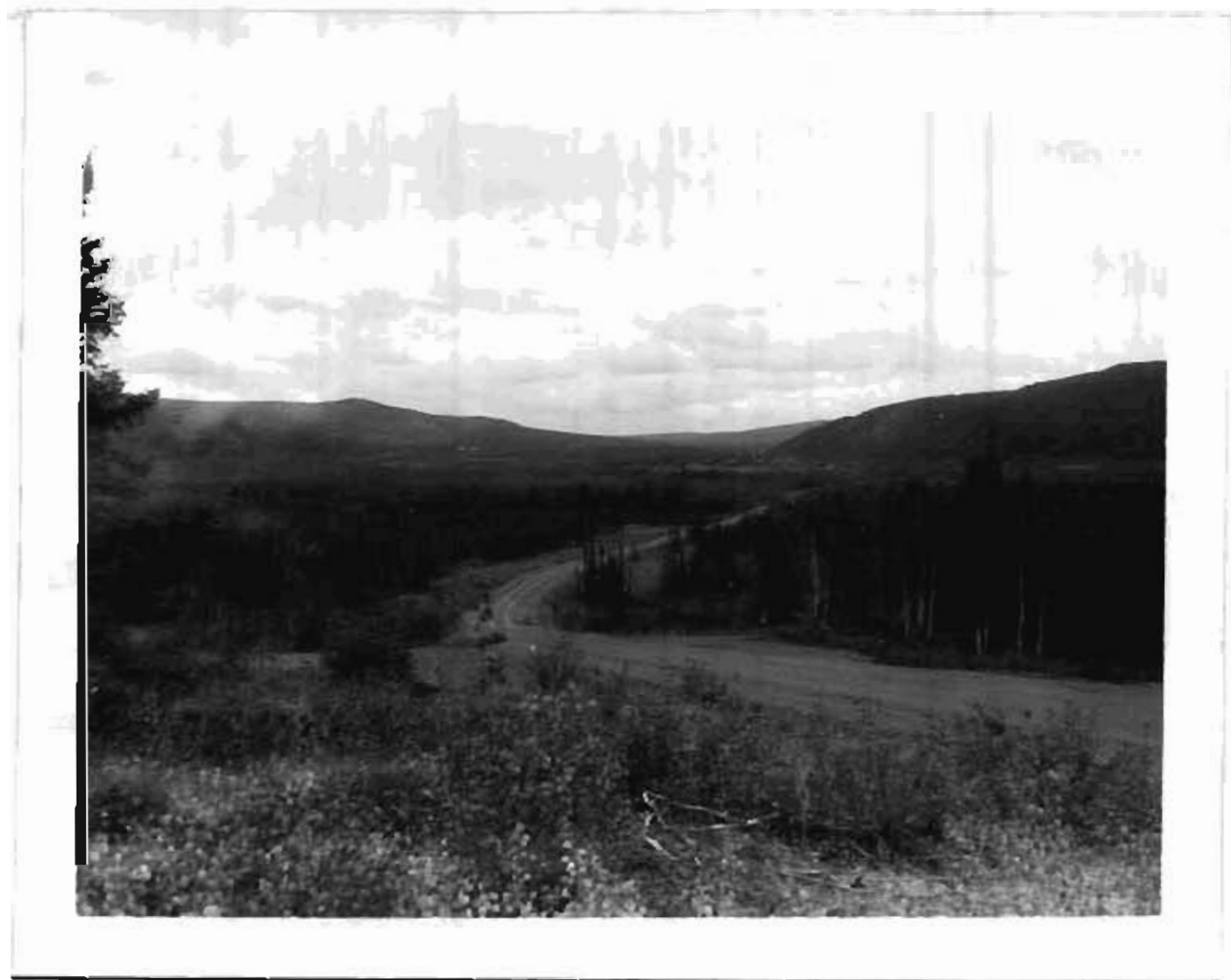

Mg. 2. View up Livengood Creok from the road toward sturaka. 


\section{RAYPARI DISTRYCT.}

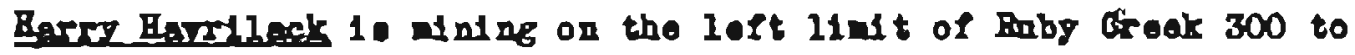
400 leot upetrean from the out that he was of nfug in 1967, when he first

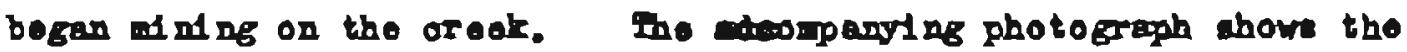
total longth of ground that ho has ad ned. Spparently there was no mochanical minlag done on Hubj Greok before he etarted nining there, but there was drift and and open-ont nining bo hand. Harrilack 1. using the seco equipment and the same mining nothod that he was using won lant roported on in 1957. At the tine of 1 . Idt, the purp box

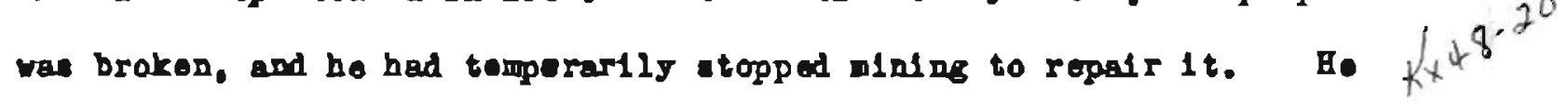
formarly wa U. S. Obmisteloner at Rampart and now 1s the Stato Kagi a trate; he goes to Rampart each Sunday to porform any rork that arlsen in conneotion wh that position.

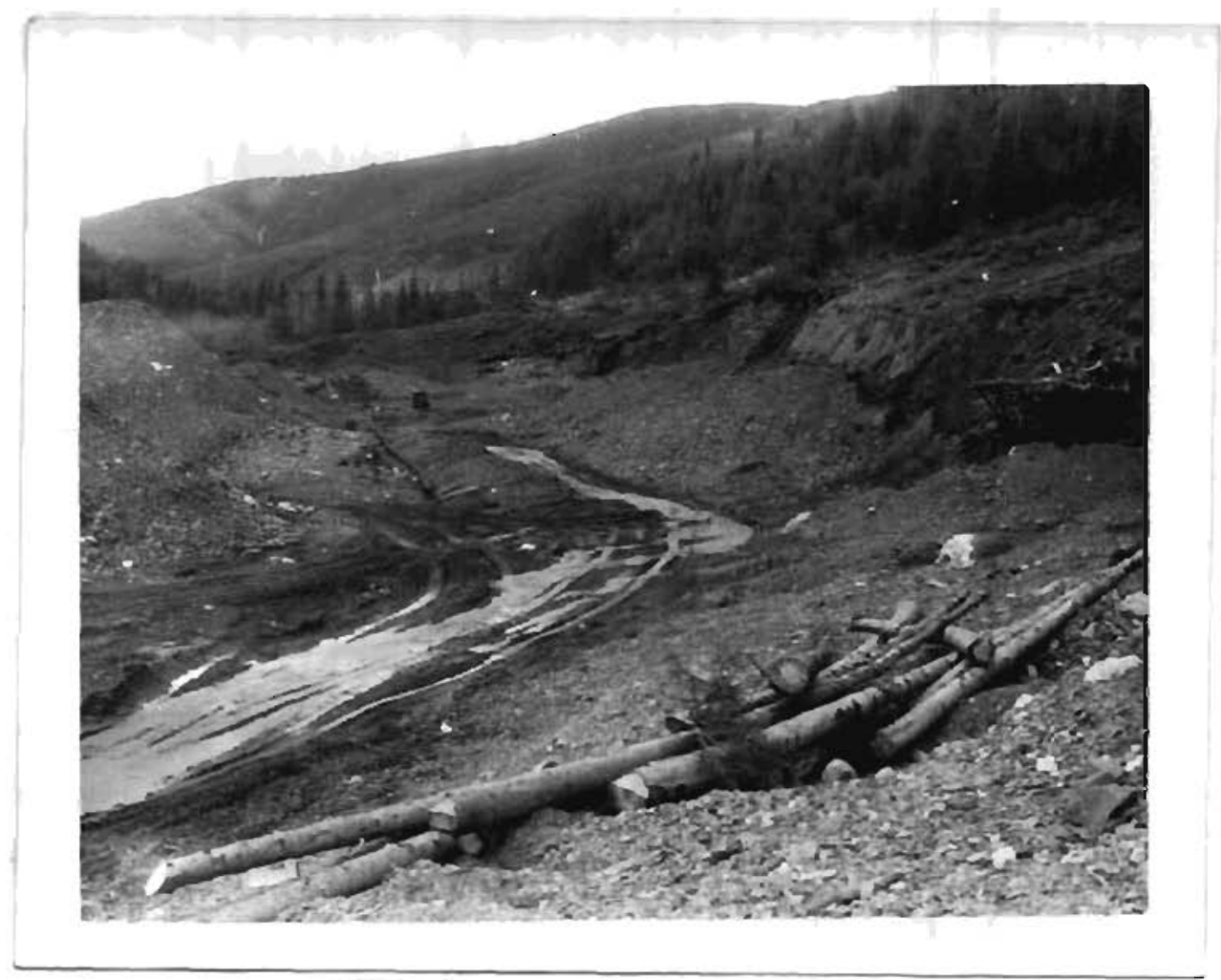

Mg. 3. Harry Harrlade's inding cut on Ruby Crook. 


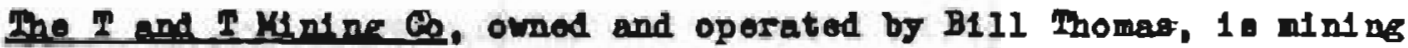
on tho 2oft Iint of Honter Crook a fow hundred foot upetream from the aito of the 1967 operatlons. III of the evamer through Jaly vas epent In otrlpping wh two nont tor preparatory to ning a large cut in mguet and September. The Hning and the oqufpent ared 1t the sam as In 1957, howerer, the tractor being ueed 1. a Geterplilar Dw Instead of a D-8 an orroneounly otated In the 1957 report.

In 1989, B11l Thones Mined oni ont on Mlate Grook on groond orned by gilliard Amet, who is no longer in Aaks. Ho roported that readte vere not good onoget for hil to leave Runter Groek, where ho $k+4 S^{-1}$ 1s al roady ostablishod and where the cont of transportation fron Bampart 1. mueh lover, but be thought that slate Grook bad poselbilities.

The Velingr Ireding, owned by Ira Melenor of Rampart, mined until

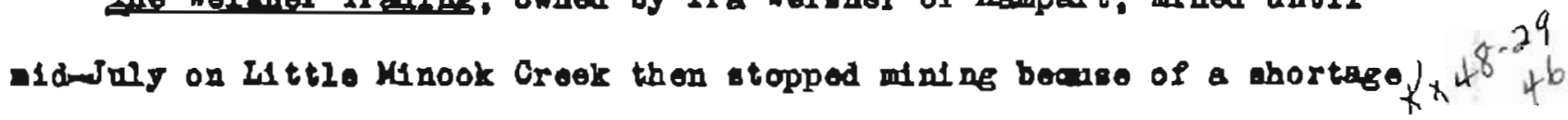
of water. Tro mont tora and a D.6 vero used for mining, and a draglino was used for stacking talling. Men anling oeneed, the eluteo bor ras placed in podtion for mining the noxt out, wh has been etripped, and Vol ener planned to reme nining if late samar rain made water nore plentisul.

The valleg of LIttle Mnook Greak is narrow, and the paratroak Is 60 to 70 feot wide. \$ strip of umined ground 2000 foet lons axtends from the uppor end of Welener's last cut to the lower ond of a mined-ont ares on the upper part of the erook. Tht minod-out area extreade to Fabor Hine Pup, a rlght-11mit tributary, wiah, accordm Ing to Velener, Io at the upper and of the payatreak. It thus appeare that only a 2000-feetrlong atrlp along the valleg ramaln to be mined. 


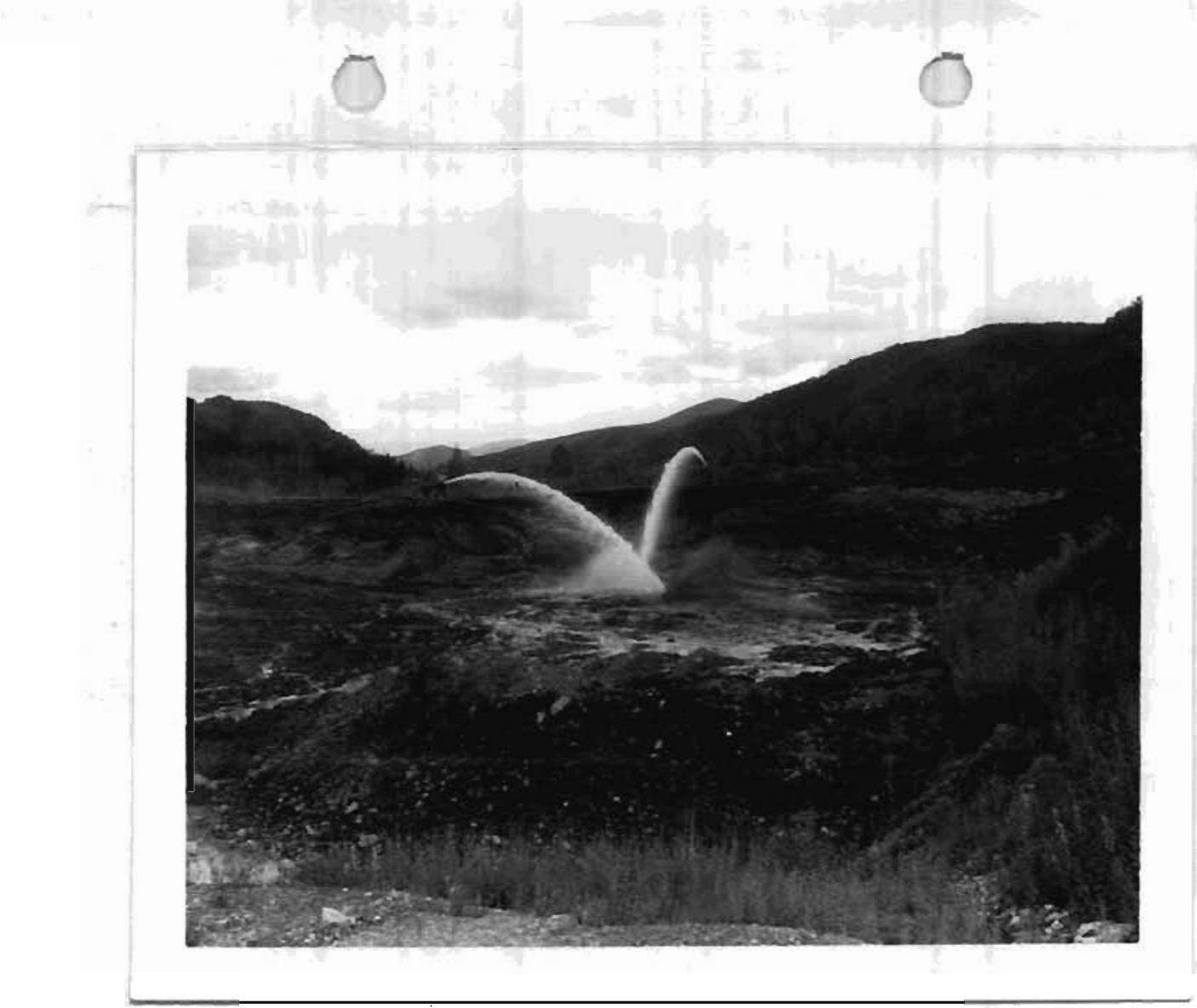

Mg. 4. T and I Mining co otripplag operation on Hanter Greek. $+x+x^{8-x^{3}}$

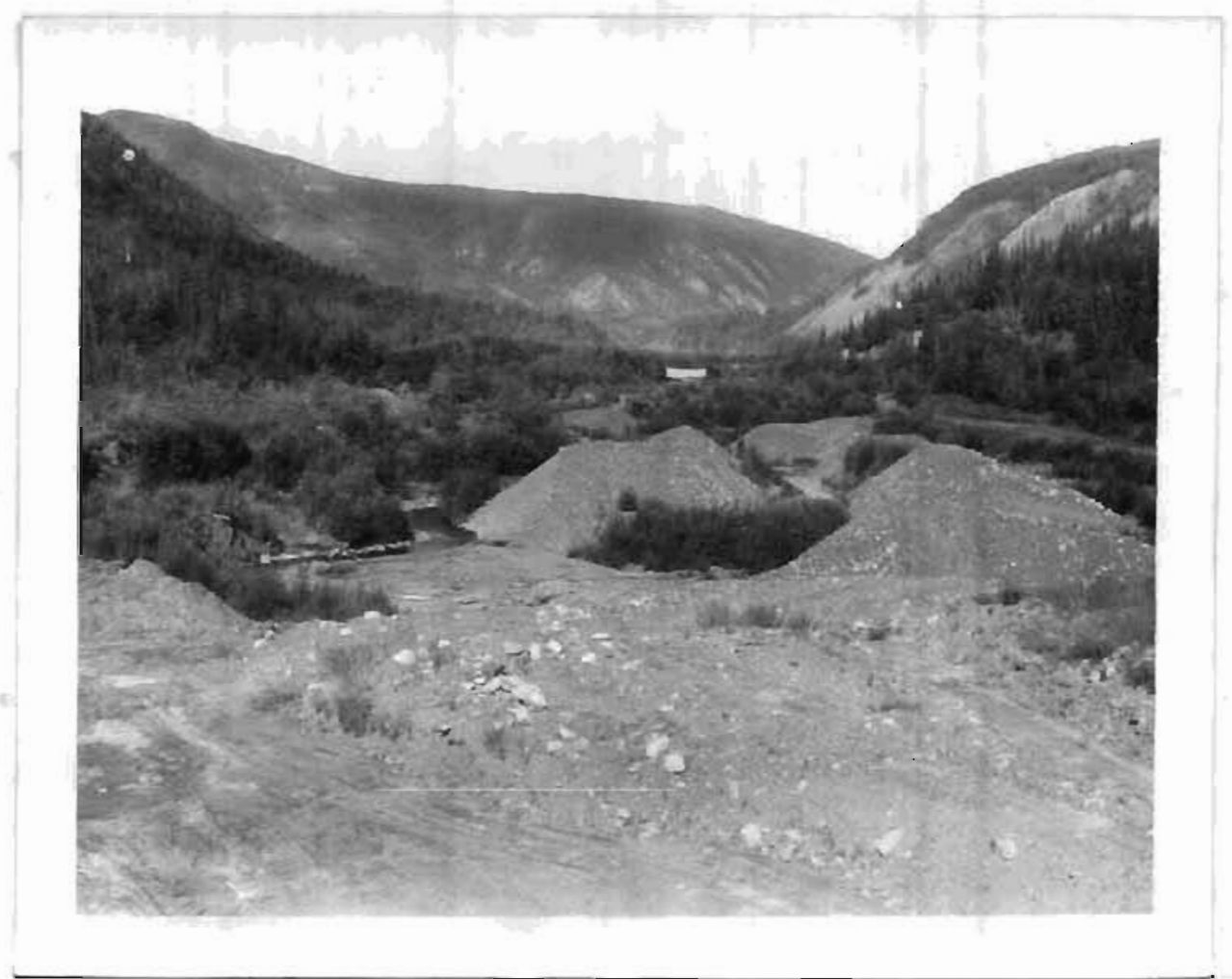

Ng. 5. T1ew dom Bunter Geok Irom upper ond of $T$ and I Mining cos eround. 
Wolener was proparing to tert mining on the rigtt limlt of Boogier Geok about one aile from the mouth. Ho Intended to use a Dw6 tractor

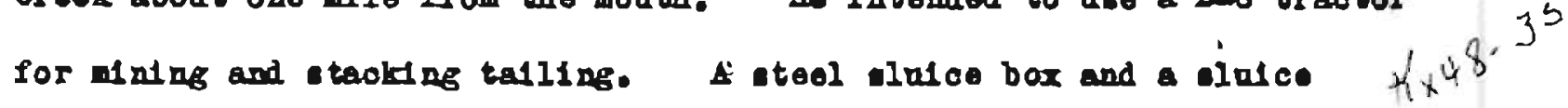
plate had beon brought over froll Llttle Mnook Grook. Hooner Creek had moro than onough water for mining.

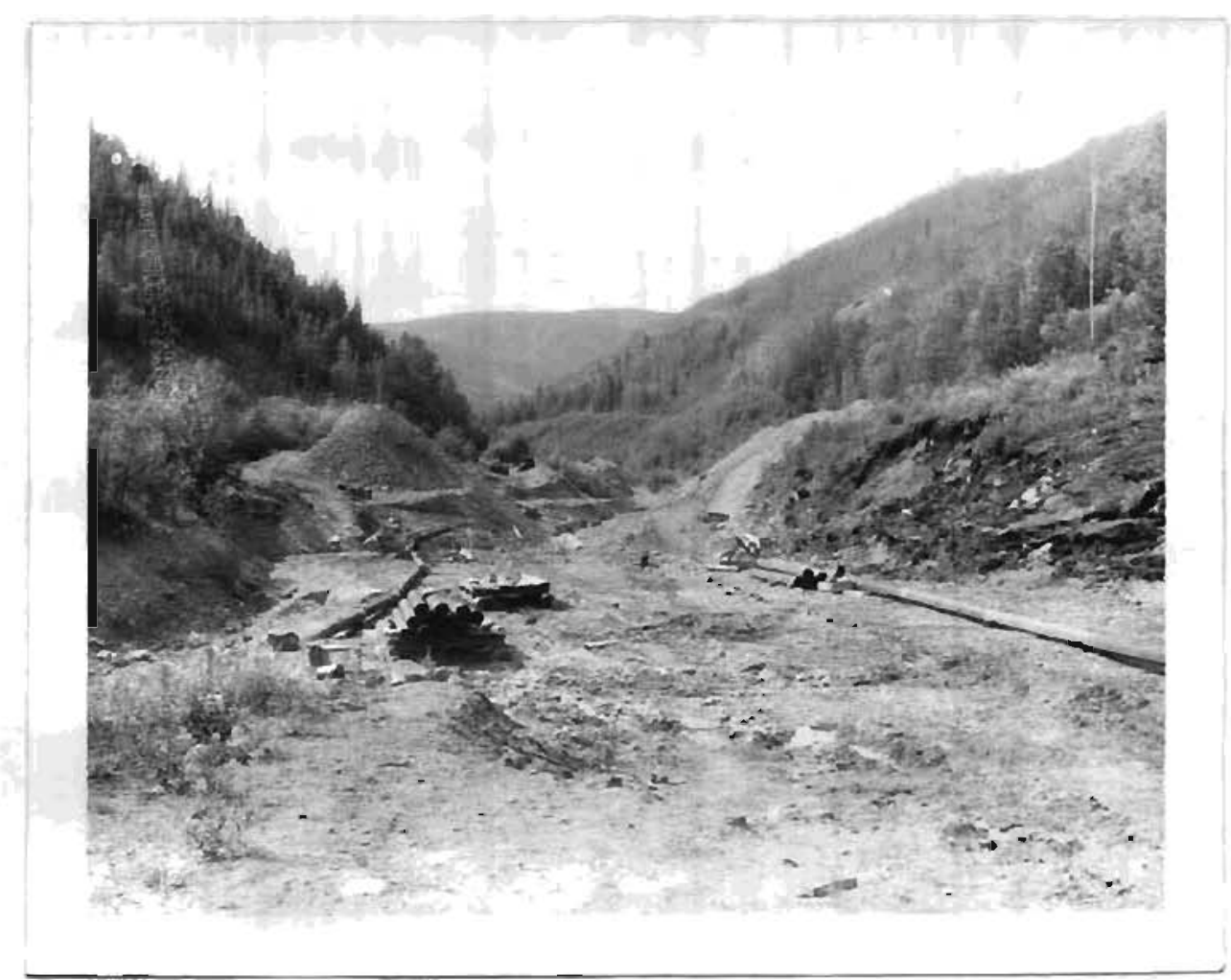

F1g. 6. V1ar down little Mnook Greok. Stripped cut in the forogroond.

Brian Koopdrte of Raupart did nome hand minting lntermittentig

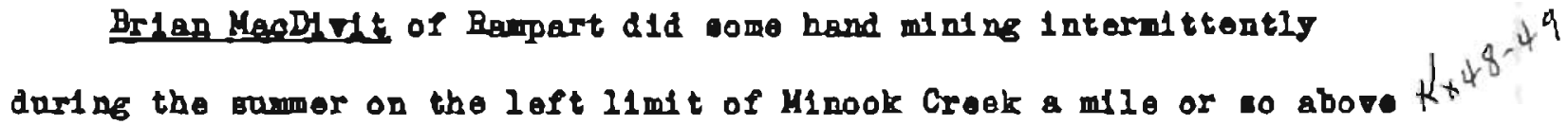
the month of Buby Cresk, but he was not at hlo vorkd nge during the t1mo thet I was in tho aros. 
MUREA DISTRICT.

Strandberz and Sonn have moved the of te of thelr minling operationo ance lagt Fisted in 1958; they are noy minting on the bench on the right limlt of Bareka Creak one-quarter mile southwest of thoir oamp butldings. Mintag mothods and oqujpient uged are the same as before.

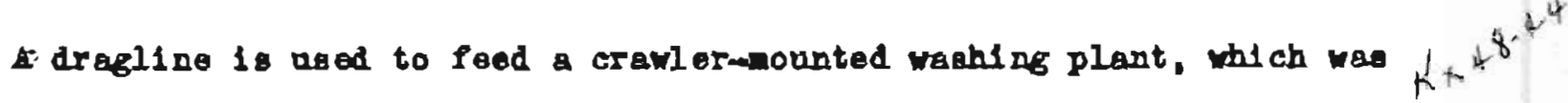
dosigned and ballt by the Wablington Iron Works. The plant 1: moved by taring it Hih a D-8 Caterplllar tractor. The staker belt. trommel, and purpe on the plant are driven by electric motor, and

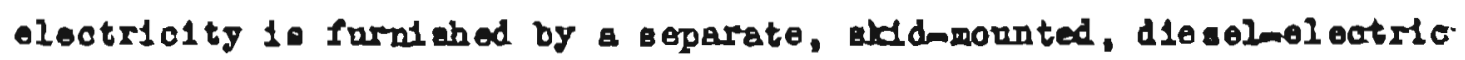
gonerator. The plant was belug moved to a nev setrp at the time of my Felt.

Pete Johnen mines alone by hydranlichng on the right $11 \mathrm{mlt}$ of Thareke Creak approdmetely one-half mile upetream fron the mouth of American creek. Water for mining cones through a ditch from a rigt- f $^{+}$ limit trlbutarg to Threkn Oreek one mile upatream from the out. Be mines in "splasheg" by alloulas the weter to back up until the diteh 1. nearly foll, gettling one 16-mingte oplash every two or three houra. One mont tor 18 ased for ninf ng and ode leads by-water to the sladce box through a plpe. The luloe box 1s of rood, and a rooden flume carriog awd the talling.

Arohte Prinele Mined during the firet pert of the sumer on the apper part of thode Inland areek. In July he wa atripplas a now out on the leftalint bench of the creok juet bolow the month of bold Hun. $x$ buldozer and one montor wer beligg aged for etripplngt: In minting, the balldoger 1s uged to feed the eluloo bor and to tack talling. One man 10 exployed. 


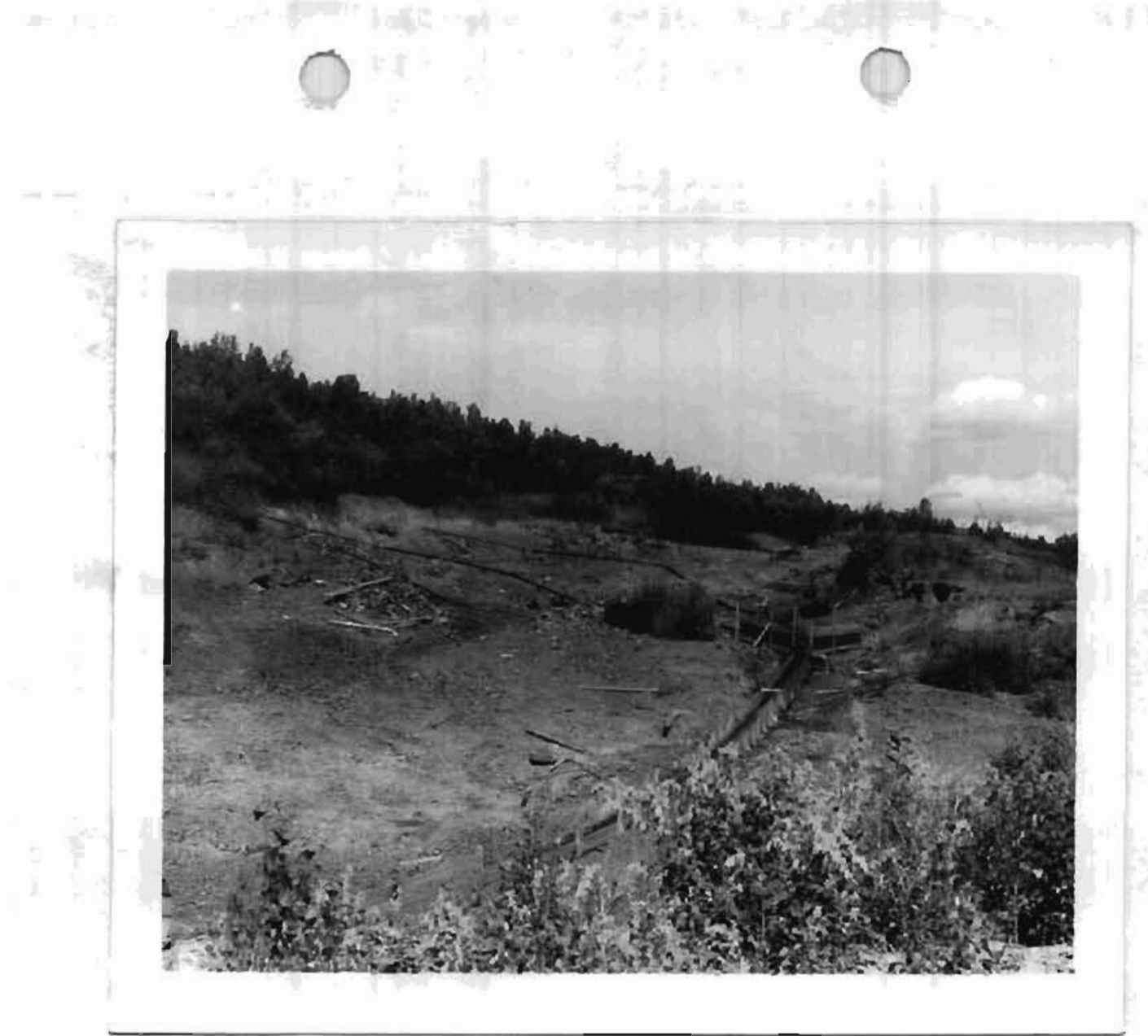

Mg. 7. Pete Johneon's nining operation on Bureka Croek.

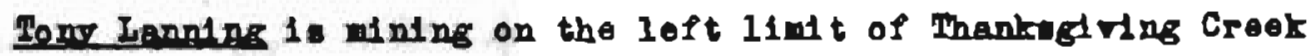

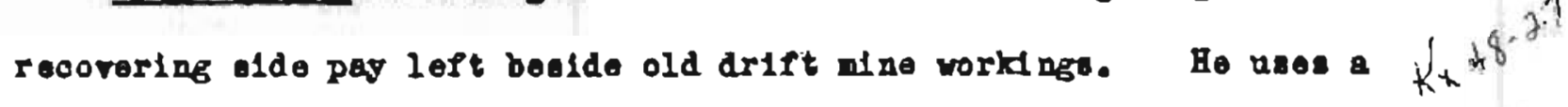
bulldozer to mine and to etack talling and a mont tor to wach the gravel 1nto the bores. He works alone. The total depth of ground being mined 1. 18 to 20 foet, 4 to 5 feat being gravel. By late Joly, he had mined one ent and was starting on the second out of the seraon.

Collego, Alagk Jamery, 1961
Robart B. Saundar:

State Mining Inglneer 